\title{
Identification and characterization of a mammalian 14-kDa phosphohistidine phosphatase
}

\author{
Pia Ek', Gunilla Pettersson', Bo Ek ${ }^{2}$, Feng Gong ${ }^{1}$, Jin-Ping Li' ${ }^{1}$ and Örjan Zetterqvist ${ }^{1}$ \\ ${ }^{1}$ Department of Medical Biochemistry and Microbiology, Uppsala University, Uppsala, Sweden; ${ }^{2}$ Department of Plant Biology, \\ The Swedish University of Agricultural Sciences, Uppsala, Sweden
}

Protein histidine phosphorylation in eukaryotes has been sparsely studied compared to protein serine/threonine and tyrosine phosphorylation. In an attempt to rectify this by probing porcine liver cytosol with the phosphohistidinecontaining peptide succinyl-Ala-His(P)-Pro-Phe-p-nitroanilide (phosphopeptide I), we observed a phosphatase activity that was insensitive towards okadaic acid and EDTA. This suggested the existence of a phosphohistidine phosphatase different from protein phosphatase 1, 2A and 2C. A 1000-fold purification to apparent homogeneity gave a 14-kDa phosphatase with a specific activity of 3 $\mu \mathrm{mol} \cdot \mathrm{min}^{-1} \cdot \mathrm{mg}^{-1}$ at $\mathrm{pH} 7.5$ with $7 \mu \mathrm{M}$ phosphopeptide I as substrate. Partial amino-acid sequence determination of the purified porcine enzyme by MS revealed similarity with a human sequence representing a human chromosome 9 gene of hitherto unknown function. Molecular cloning from a human embryonic kidney cell cDNAlibrary followed by expression and purification, yielded a protein with a molecular mass of $13700 \mathrm{Da}$, and an EDTA-insensitive phosphohistidine phosphatase activity of $9 \mu \mathrm{mol} \cdot \mathrm{min}^{-1} \cdot \mathrm{mg}^{-1}$ towards phosphopeptide I. No detectable activity was obtained towards a set of phosphoserine-, phosphothreonine-, and phosphotyrosine peptides. Northern blot analysis indicated that the human phosphohistidine phosphatase mRNA was present preferentially in heart and skeletal muscle. These results provide a new tool for studying eukaryotic histidine phosphorylation/dephosphorylation.

Keywords: dephosphorylation; N-phosphorylation; phosphoamidase; phosphopeptide; protein histidine phosphatase.
Boyer and coworkers detected protein-bound phosphohistidine in rat-liver mitochondrial succinyl-CoA synthetase almost 40 years ago [1,2]. Despite the long time interval and the fact that phosphohistidine represents a substantial fraction of eukaryotic protein-bound phosphate [3], only a few phosphohistidine-containing proteins have been detected compared to the large number of eukaryotic proteins phosphorylated on serine, threonine and tyrosine residues. One reason for this difference may be that the N-bound phosphate of phosphohistidine easily escapes detection by common analytical procedures, due to its lability under acidic conditions, e.g. during fixation and staining of gels after SDS/PAGE [4].

The studies on eukaryotic protein histidine phosphorylation and dephosphorylation have dealt with essentially two aspects. One is the intermediary phosphorylation of enzymes [5-10], of which nucleoside diphosphate kinase is a

Correspondence to J.-P. Li, Department of Medical Biochemistry and Microbiology, Box582, SE-751 23 Uppsala, Sweden.

Fax: + 4618 4714209, Tel. + 4618 4714241,

E-mail: Jin-Ping.Li@imbim.uu.se

Abbreviations: His(P), phosphohistidine; MDEA, $N$-methyl-dietha-

nolamine; phosphopeptide I, Suc-Ala-His(P)-Pro-Phe-pNA;

pNA, $p$-nitroanilide

Note: The nucleotide sequence for human 14-kDa phosphohistidine phosphatase has been submitted to the GenBank Nucleotide Sequence Database under the accession number AF393504.

(Received 9 June 2002, revised 21 August 2002,

accepted 27 August 2002) particularly well-studied example. The other is the reversible protein histidine phosphorylation by protein kinases and phosphatases $[3,11]$. An important contribution to the latter field was the purification of a yeast protein histidine kinase in 1991 [12]. Access to this enzyme also made possible the preparation of ${ }^{32} \mathrm{P}$-labelled histone $\mathrm{H} 4$, which was later used as substrate in the search for phosphohistidine phosphatases. Using such an approach, the catalytic subunits of the well-studied serine/threonine protein phosphatases $1,2 \mathrm{~A}$ and $2 \mathrm{C}$ were shown to display $k_{\text {cat }} / K_{\mathrm{m}}$ values in the order of $10^{6}-10^{7} \mathrm{M}^{-1} \cdot \mathrm{s}^{-1}$ for the phosphohistidinecontaining histone $\mathrm{H} 4$. These values were at least as high as those for their naturally occurring phosphoserine-containing substrates $[13,14]$.

Notwithstanding these findings, there is still a possibility that additional phosphohistidine phosphatases exist. For instance, a 13-kDa bovine liver phosphoamidase has been reported to possess activity also towards intermediary phosphorylated nucleoside diphosphate kinase and succinyl-CoA synthetase [15]. In a recent review [16], data in press on a $14-\mathrm{kDa}$ phosphatase from rabbit liver that dephosphorylates the phosphohistidine of autophosphorylated ATP-citrate lyase is reported [17].

In the search for new phosphohistidine phosphatases we tried a different approach. It seemed reasonable to assume that the immediate environment of the N-phosphate of protein-bound phosphohistidine can influence its sensitivity to a phosphatase. Of potential interest in such a context was the finding that the rate of isomerization of the histidineproline bond in the peptide Suc-Ala-His-Pro-Phe-pNA is influenced by the degree of protonation of its imidazole ring 
[18]. We therefore performed a chemical N-phosphorylation of the imidazole of this peptide by means of phosphoamidate, and used Suc-Ala-His(P)-Pro-Phe-pNA (phosphopeptide I) as a probe to search for new phosphohistidine phosphatases. As the result of that screening we detected a 14-kDa phosphatase in porcine liver cytosol and were also able to ascribe phophohistidine phosphatase activity to a 14-kDa protein coded for by a human chromosome 9 gene.

\section{EXPERIMENTAL PROCEDURES}

\section{Materials}

Phosphoamidate was prepared according to the method of Wei and Matthews [4]. Suc-Ala-His-Pro-Phe-pNA was purchased from Bachem AG, Switzerland. Malachite green reagent was obtained from Apoteksbolaget, Södersjukhuset, Stockholm, Sweden. MDEA was bought from Riedel de Haën. Diisopropyl fluorophosphate was from Fluka Chemie AG, Switzerland. Phenylmethanesulfonyl fluoride and okadaic acid were from Sigma. Trypsin of modified sequencing grade was obtained from Promega, and $\mathrm{LysC}$ of Achromobacter lytii from Wako. The O-phosphorylated phosphopeptides EQTRsLDGR- $\mathrm{NH}_{2}$, DHTGFLtEYVATRWC-NH $\mathrm{N}_{2}$, DADEyL-NH $\mathrm{N}_{2}$, EGDNDyIIPL-NH $\mathrm{N}_{2}$, KKPRyEIRW- $\mathrm{NH}_{2}$, and LIEDNEyTARQGA-NH ${ }_{2}$ (phosphorylated residues indicated by lower-case) were gifts from Mrs Ulla Engström at the Ludwig Institute of Cancer Research, Uppsala. The O-phosphopeptides GRRPsLFG and APDyTTPEMY- $\mathrm{NH}_{2}$ were obtained from Dr Åke Engström at the Peptide Synthesis and Analysis Laboratory of the Department of Medical Biochemistry and Microbiology, Uppsala University. The SP6 primer 5'-ATT TAG GTG ACA CTA TAG-3' and the three oligonucleotide PCR-primers described below were from DNA Technology A/S, Denmark. The T7 primer 5'-TAA TAC GAC TCA CTA TAG GG-3' and protein molecular weight references were from Amersham Biosciences. Terminator ready reaction mix was from PE Biosystems. DEAE cellulose (DE-52) was from Whatman, Sephadex G-200 Fine, Mono Q HR 5/5 columns, and the gel filtration columns Sephadex G-25 PD-10, Superose 12 HR 10/30, Superose 12 PC 3.2/30, and Superdex 75 PC 3.2/30 were from Amersham Biosciences.

\section{Preparation of the phosphohistidine-containing peptide Suc-Ala-His(P)-Pro-Phe-pNA}

The protocol used was adapted from that used for the synthesis and isolation of free 3-phosphohistidine by Wei and Matthews [4]. Phosphoamidate $(275 \mathrm{~mm})$ and the peptide Suc-Ala-His-Pro-Phe-pNA (25 mM) were incubated at room temperature for $48 \mathrm{~h}$ in a total volume of $200 \mu \mathrm{L}$. The mixture was then diluted with $2 \mathrm{~m}$ MDEA, $\mathrm{pH}$ 9.0, and $100 \%$ methanol to give $1.6 \mathrm{~mm}$ peptide in $0.13 \mathrm{~m} \mathrm{MDEA} /$ $20 \%$ methanol, and applied to a 1-mL Mono Q column equilibrated with 0.13 M MDEA, $\mathrm{pH} 9.0$, containing $20 \%$ methanol. After washing with $2 \mathrm{~mL}$ of equilibration buffer, the phosphopeptide was eluted with a $25-\mathrm{mL}$ linear gradient of $0.13-1.17 \mathrm{~m}$ MDEA in $20 \%$ methanol at $1 \mathrm{~mL} \cdot \mathrm{min}^{-1}$. The pNA-containing phosphopeptide I, which was traced by its absorbance at $315 \mathrm{~nm}$, appeared as a peak at $0.33 \mathrm{M}$ MDEA and was essentially stable in this buffer at $+4{ }^{\circ} \mathrm{C}$ for at least 4 months. The phosphate content of the phosphopeptide was analysed by the malachite green method [19]. The peptide concentration was calculated by using the molar absorbancy 13600 of pNA at $315 \mathrm{~nm}$. The nature of the phosphohistidine isomer in phosphopeptide I was not determined, but it was considered to be 3-phosphohistidine, rather than 1-phosphohistidine, due to the $48 \mathrm{~h}$ phosphorylation time used $[4,20]$.

\section{Phosphatase assays}

The standard assay of the phosphohistidine phosphatase activity was performed at $30^{\circ} \mathrm{C}$ and $\mathrm{pH} 7.5$ in a $150-\mu \mathrm{L}$ reaction mixture consisting of $25 \mathrm{~mm}$ Hepes, $15 \mathrm{~mm}$ MDEA, $1 \mathrm{~mm} \mathrm{MgCl}_{2}$ and $7 \mu \mathrm{m}$ phosphopeptide I. The reaction was stopped after 10-30 min by addition of $2 \mathrm{M}$ $\mathrm{KOH}$ to give $\mathrm{pH}$ 12.5. After $10 \mathrm{~min}$ incubation at $0{ }^{\circ} \mathrm{C}, 1 \mathrm{M}$ $\mathrm{HCl}$ was added to give $\mathrm{pH} 9.0$. The mixture was then applied to a 1-mL Mono Q column equilibrated in $0.085 \mathrm{M}$ MDEA, pH 9.0, in $20 \%$ methanol. After washing with $2 \mathrm{~mL}$ of the equilibration buffer, elution was performed with a $25-\mathrm{mL}$ linear gradient of MDEA from $0.085 \mathrm{~m}$ to $0.765 \mathrm{M}$ in $20 \%$ methanol at $1 \mathrm{~mL} \cdot \mathrm{min}^{-1}$. The absorbance at $315 \mathrm{~nm}$ was monitored and the degree of dephosphorylation was calculated from the peak areas of phosphorylated and dephosphorylated peptides. In a control experiment, the stoichiometry of the cleavage was confirmed by the occurrence of equal amounts of orthophosphate and unphosphorylated Suc-Ala-His-Pro-Phe-pNA. The identity of the peptide product was controlled by amino acid analysis.

In initial phosphohistidine phosphatase assays with porcine liver cytosol, the phosphorylated and dephosphorylated peptides were separated on a 24-mL Superose 12 column in $0.10 \mathrm{~m}$ MDEA, pH 9.0. In this system, phosphopeptide I was eluted after 0.5 column volumes, whereas the corresponding dephosphopeptide was eluted after 0.9 column volumes. Both peptides were traced by the absorbance at $315 \mathrm{~nm}$.

Phosphoamidase activity of the porcine liver phosphohistidine phosphatase was assayed by incubating the phosphatase with $1 \mathrm{~mm}$ phosphoamidate in $25 \mathrm{~mm}$ Hepes, $\mathrm{pH} \mathrm{7.5,} \mathrm{at} 30^{\circ} \mathrm{C}$ for $30 \mathrm{~min}[15]$. The released orthophosphate was measured by a modification of the method of Martin and Doty [21], using toluene instead of benzene. To keep background hydrolysis of the acid-labile phosphoamidate as low as possible, the sample $(200 \mu \mathrm{L})$, isobutanol/ toluene $1: 1(250 \mu \mathrm{L})$, and $5 \%$ ammonium molybdate in $2 \mathrm{M} \mathrm{H}_{2} \mathrm{SO}_{4}(50 \mu \mathrm{L})$ were added in that order, and extraction was performed by immediate vortex-mixing in a capped Eppendorf test-tube for $15 \mathrm{~s}$, followed by centrifugation in an Eppendorf centrifuge at $8000 \mathrm{~g}$ for $1 \mathrm{~min}$. The phosphomolybdate was determined by the absorbance at $720 \mathrm{~nm}$ obtained after mixing $130 \mu \mathrm{L}$ of the organic phase with $130 \mu \mathrm{L}$ of acid ethanol and $6.25 \mu \mathrm{L}$ of dilute $\mathrm{SnCl}_{2}$, prepared as described [21].

The activity of human recombinant phosphohistidine phosphatase, prepared as described below, was tested against the eight O-phosphopeptides containing phosphoserine, phosphothreonine or phosphotyrosine, described under Materials. The phosphopeptides were incubated at $50 \mu \mathrm{M}$ final concentration under the conditions of the standard phosphohistidine phosphatase assay. The reaction was interrupted by mixing $100 \mu \mathrm{L}$ aliquots of the reaction 
mixtures with $100 \mu \mathrm{L}$ of $1 \mathrm{M} \mathrm{HCl}$ in a 96-well microtitration plate, followed by $50 \mu \mathrm{L}$ of malachite green reagent [19]. After $60 \mathrm{~min}, A_{620}$ was measured in a Titertek ${ }^{\circledR}$ Multiskan from Flow Laboratories.

\section{Preparation of porcine liver cytosol}

For small-scale preparation of cytosol, $10 \mathrm{~g}$ of fresh porcine liver obtained from the local abattoir was homogenized for $1 \mathrm{~min}$ at 600 r.p.m. in three volumes of homogenization buffer $(0.25 \mathrm{~m}$ sucrose, $10 \mathrm{~mm}$ Hepes, $\mathrm{pH} 7.5,1 \mathrm{~mm}$ EDTA and $1 \mathrm{~mm}$ diisopropyl fluorophosphate) using a 50-mL Potter-Elvehjem homogenizer with a loose-fitting Teflone rotor (diameter of $24.6 \mathrm{~mm}$ ). This was followed by one stroke of a standard, tight-fitting rotor $(25.2 \mathrm{~mm})$. For large-scale preparations, batches of $100 \mathrm{~g}$ porcine liver each were homogenized in a 1-L Turmix mixer for $10 \mathrm{~s}$ at full speed. In both cases, the homogenates were centrifuged at $600 \mathrm{~g}$ for $10 \mathrm{~min}$ in a refrigerated centrifuge, followed by centrifugation of the supernatant at $14500 \mathrm{~g}$ for $5 \mathrm{~min}$. The latter supernatant was then centrifuged at $45500 \mathrm{~g}$ for $2 \mathrm{~h}$.

\section{Purification of phosphohistidine phosphatase from porcine liver cytosol}

A mixture of $320 \mathrm{~mL} 10 \mathrm{~mm}$ Hepes, $\mathrm{pH} 7.5$ and $320 \mathrm{~mL}$ of cytosol from $130 \mathrm{~g}$ of liver, was stirred for one hour with $600 \mathrm{~mL}$ of DEAE-cellulose, equilibrated in $25 \mathrm{~mm}$ Hepes, $\mathrm{pH}$ 7.5. The slurry was then packed into a column $(6.5 \times 18 \mathrm{~cm})$, washed with $3600 \mathrm{~mL}$ of equilibration buffer, and eluted with a $2000 \mathrm{~mL}$ linear gradient of $0-0.5 \mathrm{M}$ $\mathrm{NaCl}$ in equilibration buffer. The phosphohistidine phosphatase, which appeared at $0.15 \mathrm{M} \mathrm{NaCl}$, was concentrated fivefold with a Diaflo membrane YM-10, Amicon. The material was divided into two 10-mL aliquots, each of which was chromatographed on a Sephadex G-200 column $(3 \times 30.5 \mathrm{~cm})$ in $50 \mathrm{~mm}$ Hepes, $\mathrm{pH} 7.5$. Fractions with phosphohistidine phosphatase activity were pooled, diluted with one volume of water and filtered through a $0.2-\mu \mathrm{m}$ Millipore filter. A total of $20 \mathrm{~mL}$, representing $50 \%$ of the material from one G-200 column, was loaded onto a 1-mL Mono Q column equilibrated in $25 \mathrm{~mm}$ Hepes, pH 7.5. Elution was performed with a $20-\mathrm{mL}$ linear gradient of $0-0.5 \mathrm{M} \mathrm{NaCl}$ in equilibration buffer at a flow-rate of $1 \mathrm{~mL} \cdot \mathrm{min}^{-1}$. The enzyme, which appeared at $80 \mathrm{~mm} \mathrm{NaCl}$, was further purified on a 2.4-mL Superose-12 column equilibrated and eluted with $25 \mathrm{~mm}$ Hepes, pH 7.5, containing $150 \mathrm{~mm} \mathrm{NaCl}$. All purification steps were performed at $4{ }^{\circ} \mathrm{C}$. Protein was estimated from the absorbance at $280 \mathrm{~nm}$ [22]. The purified protein was analysed by SDS/ PAGE [23].

\section{Amino acid sequencing by MS}

Samples containing purified porcine liver phosphohistidine phosphatase were digested with trypsin or LysC as described [24]. The peptide mixtures were analysed by MS and sequence determinations of selected peptides were performed by $\mathrm{MS} / \mathrm{MS}$ in a Q-tof mass spectrometer, equipped with a nanospray interface (Micromass, Manchester, UK). All MS data were processed and analysed with MASSLYNX software programs.

\section{RNA isolation and molecular cloning of human} phosphohistidine phosphatase CDNA

Human embryonic kidney cells (HEK293) were grown in Dulbecco's modified Eagle's medium supplemented with $10 \%$ fetal bovine serum, $60 \mu \mathrm{g} \cdot \mathrm{mL}^{-1}$ of penicillin and $50 \mu \mathrm{g} \cdot \mathrm{mL}^{-1}$ of streptomycin until confluence. The cells were trypsinized and washed with $\mathrm{NaCl} / \mathrm{P}_{\mathrm{i}}(15 \mathrm{~mm}$ phosphate buffer, $\mathrm{pH} 7.4$, in $135 \mathrm{~mm} \mathrm{NaCl}$ ). Total RNA was extracted according to the $\mathrm{LiCl} /$ urea/SDS procedure of Sambrook et al. [25]. About $1 \mu \mathrm{g}$ of the RNA was used as template for RT-PCR. Single strand cDNA was prepared in a volume of $20 \mu \mathrm{L}$ with First Strand cDNA Synthesis Kit for RT-PCR (Roche). The PCR apparatus was a PTC 100 from MJ Research Inc.

A portion $(2 \mu \mathrm{L})$ of the single strand cDNA was used for amplification of the potential phophohistidine phosphatase cDNA. The PCR primers were based on a human nucleotide sequence reported from GenBank (accession number AF164795) which contained a putative 378 bp coding domain for a protein containing sequences homologous to peptides of the purified porcine protein. The sense primer (5'-ATG GCG GTG GCG GAC CTC GCT CTC AT-3') corresponded to bp 9-34 of AF164795 and the antisense primer (5'-TCA GTA GCC GTC GTT AGC CCA GGT GA-3') corresponded to bp 361-386 at the $3^{\prime}$-end, including the stop codon. PCR was performed under the conditions: 1 cycle of $95{ }^{\circ} \mathrm{C}$ for $3 \mathrm{~min}, 35$ cycles each of $95{ }^{\circ} \mathrm{C}$ for $30 \mathrm{~s}, 68^{\circ} \mathrm{C}$ for $30 \mathrm{~s}$ and $72{ }^{\circ} \mathrm{C}$ for $1 \mathrm{~min}$, and a final extension at $72{ }^{\circ} \mathrm{C}$ for $10 \mathrm{~min}$. The PCR product was $3^{\prime}$-adenylated, inserted into the TOPO-TA Cloning Vector pCR ${ }^{\circledR}$ II TOPO, and transformed to a competent bacterium (TOP10, Invitrogen), as described in the protocol provided by the manufacturer. One of the clones that contained the complete coding sequence was chosen for further processing.

\section{Nucleotide sequencing}

Nucleotide sequencing was performed on clones of the pCR ${ }^{\circ}$ II TOPO (Invitrogen) and pET-24a $(+)$ (Novagen) vectors carrying the inserts. T7 and Sp6 primers were used for both sense and antisense strands. The BigDye terminator method from Perkin-Elmer was used according to the instructions of the manufacturer. Sequencing was carried out in ABI Prism 310 Genetic Analyser from Perkin-Elmer.

\section{Expression of the human phosphohistidine phosphatase recombinant protein}

In order to permit the expression of a protein without tags, an expression construct was generated using the chosen clone as the template. The sense primer used was $5^{\prime}$-CAT ATG GCG GTG GCG GAC CTC GCT-3', corresponding to nucleotides $1-21$ of the coding sequence, preceded by a NdeI cleavage site at the $5^{\prime}$-end. The antisense primer was the same as used for cloning. When the sequence had been confirmed, the insert was cut out by NdeI and NotI, and subsequently ligated into the expression vector pET$24 \mathrm{a}(+)$. The expression construct was introduced into BL21(DE3) bacterial cells and selected on LB-agar plates containing kanamycin $\left(50 \mu \mathrm{g} \cdot \mathrm{mL}^{-1}\right)$. Single colonies were picked and cultured at $37^{\circ} \mathrm{C}$ with and without $1 \mathrm{~mm}$ 
isopropyl thio- $\beta$-D-galactoside in $5 \mathrm{~mL} \mathrm{LB}$ medium containing kanamycin $\left(50 \mu \mathrm{g} \cdot \mathrm{mL}^{-1}\right)$. Cells were collected and lysed in $0.5 \mathrm{~mL}$ of $25 \mathrm{~mm}$ Hepes ( $\mathrm{pH} 7.5$ ) containing $2 \mathrm{~mm}$ phenylmethanesulfonyl fluoride, $10 \mu \mathrm{g} \cdot \mathrm{mL}^{-1}$ pepstatin $\mathrm{A}$, $100 \mu \mathrm{g} \cdot \mathrm{mL}^{-1}$ lysozyme and $5 \mathrm{~mm}$ EDTA. After freezing, thawing, and ultrasonic treatment the supernatant was collected and analysed for phosphohistidine phosphatase activity.

The clone with the highest activity was cultured in $500 \mathrm{~mL} \mathrm{LB}$ medium at $37{ }^{\circ} \mathrm{C}$ in the presence of kanamycin $\left(50 \mu \mathrm{g} \cdot \mathrm{mL}^{-1}\right)$ to an absorbance of 0.64 at $600 \mathrm{~nm}$. Expression of the recombinant protein was then induced by addition of isopropyl thio- $\beta$-D-galactoside $(1 \mathrm{~mm})$. After $6 \mathrm{~h}$, the cells were collected by centrifugation at $+4{ }^{\circ} \mathrm{C}$ and $4000 \mathrm{~g}$ for $10 \mathrm{~min}$, washed twice in $\mathrm{NaCl} / \mathrm{P}_{\mathrm{i}}$ and frozen at $-70{ }^{\circ} \mathrm{C}$. The frozen pellet was later thawed, suspended in $10 \mathrm{~mL} 25 \mathrm{~mm}$ Hepes buffer, $\mathrm{pH} 7.5$, containing $2 \mathrm{~mm}$ phenylmethanesulfonyl fluoride, $10 \mu \mathrm{g} \cdot \mathrm{mL}^{-1}$ pepstatin A and $5 \mathrm{~mm}$ EDTA and passed four times through a French Press. The cell lysate was centrifuged at $17000 \mathrm{~g}$ for $10 \mathrm{~min}$ and the resulting supernatant was used for purification of the recombinant protein.

\section{Purification of the recombinant phosphohistidine phosphatase}

A 9-mL sample of the supernatant of the bacterial lysate was chromatographed on a Sephadex G-200 column $(3 \times 30.5 \mathrm{~cm})$, in $50 \mathrm{~mm}$ Hepes, $\mathrm{pH} 7.5$. The fractions containing the phosphatase activity were pooled to give $38 \mathrm{~mL}$, of which $34 \mathrm{~mL}$ was diluted with $34 \mathrm{~mL}$ of water and loaded onto a 1-mL DEAE-cellulose column equilibrated with $25 \mathrm{~mm}$ Hepes, $\mathrm{pH}$ 7.5. Elution was performed with a $10-\mathrm{mL}$ gradient of $0-0.5 \mathrm{M} \mathrm{NaCl}$ in the same buffer, at $0.5 \mathrm{~mL} \cdot \mathrm{min}^{-1}$. Phosphohistidine phosphatase activity was assayed with phosphopeptide I as the substrate. Protein was estimated from the absorbance at $280 \mathrm{~nm}$ [22] and by the Bradford method using bovine serum albumin as standard [26]. Chromatographic fractions were analysed by SDS/PAGE [23]. The size of the active, purified recombinant phosphohistidine phosphatase was estimated by chromatography on Superdex 75 in $25 \mathrm{~mm}$ Hepes, $\mathrm{pH} 7.5$, containing $150 \mathrm{~mm} \mathrm{NaCl}$. Amino acid sequencing of tryptic fragments was performed by MS as described above. The intact recombinant protein was also analysed by MS.

\section{Northern blot analysis}

The cDNA of the full coding sequence of the human phosphohistidine phosphatase was labelled with $\left.{ }^{32} \mathrm{P}\right] \mathrm{dCTP}$ in a reaction with Klenow enzyme (Roche), and used as a probe in hybridization to a Human Multiple Tissue Northern (MTN®) blot (Clontech). The amount of mRNA was claimed by the manufacturer to be the same in each lane of this blot. The hybridization was carried out in ExpressHyb Hybridization Solution (Clontech) at $60{ }^{\circ} \mathrm{C}$ for one hour and the blot was then washed with $0.1 \times \mathrm{NaCl} / \mathrm{Cit}$ containing $0.5 \%$ SDS at $60{ }^{\circ} \mathrm{C}(1 \times \mathrm{NaCl} / \mathrm{Cit}$ was $150 \mathrm{~mm}$ $\mathrm{NaCl}$ in $15 \mathrm{~mm}$ sodium citrate, $\mathrm{pH}$ 7.0). The membrane was exposed to an X-ray film for 2 days.

\section{RES ULTS}

\section{Probing for a potential phosphohistidine phosphatase in porcine liver cytosol}

After passage through a column of Sephadex G-25 (PD-10), porcine liver cytosol showed a phosphohistidine phosphatase activity of $0.003 \mu \mathrm{mol} \cdot \mathrm{min}^{-1} \cdot \mathrm{mg}^{-1}$ protein when tested against $7 \mu \mathrm{M}$ phosphopeptide I. No inhibition of the dephosphorylation was observed in the presence of $1 \mu \mathrm{M}$ okadaic acid, nor did $1 \mathrm{~mm}$ EDTA in the absence of $1 \mathrm{~mm}$ magnesium chloride inhibit the enzyme.

\section{Purification of phosphohistidine phosphatase from porcine liver}

A phosphohistidine phosphatase with the specific activity $3 \mu \mathrm{mol} \cdot \mathrm{min}^{-1} \cdot \mathrm{mg}^{-1}$ at $\mathrm{pH} 7.5$, measured with $7 \mu \mathrm{M}$ phosphopeptide I was obtained after a 1000-fold purification from the porcine liver cytosol (Table 1). At $\mathrm{pH} 5.6$, the activity was only $9 \%$ of that at $\mathrm{pH} 7.5$. No activity was detected at $\mathrm{pH} 9.0$. The specific activity toward $1 \mathrm{~mm}$ phosphoamidate was $0.6 \mu \mathrm{mol} \cdot \mathrm{min}^{-1} \cdot \mathrm{mg}^{-1}$. After the Mono Q step, the enzyme could be stored at $-20{ }^{\circ} \mathrm{C}$ for 1 year with less than $50 \%$ loss of activity. The last purification step on Superose 12 gave an apparently pure protein with a $K_{\mathrm{av}}$ of 0.5 , almost equal to the reference protein pancreatic ribonuclease, with the known molecular mass of $13.7 \mathrm{kDa}$. On SDS/PAGE, the purified material migrated as a single band with an apparent molecular mass of $14 \mathrm{kDa}$ (not shown). These results indicated that the purified, active enzyme was monomeric.

\section{Amino acid sequencing}

In order to clone the enzyme, amino acid sequencing by MS was performed on peptides obtained by digestion of the purified porcine enzyme with trypsin or LysC. The resulting peptide sequences are shown in Table 2. Using these peptides as probes during searching through sequence databases, we found a cDNA from human adrenal glands (accession number AF164795) [27].

Table 1. Purification of porcine liver phosphohistidine phosphatase. The purification was performed as described under Experimental procedures.

\begin{tabular}{lcclc}
\hline Step & Total activity $\left(\mu \mathrm{mol} \cdot \mathrm{min}^{-1}\right)$ & Yield $(\%)$ & Specific activity $\left(\mu \mathrm{mol}^{\prime} \cdot \mathrm{min}^{-1} \cdot \mathrm{mg}^{-1}\right)$ & Purification factor \\
\hline Cytosol & 13.6 & 100 & 0.0028 & 1.0 \\
DEAE & 4.04 & 29.7 & 0.0043 & 1.5 \\
Sephadex G-200 & 1.98 & 14.6 & 0.053 & 18.0 \\
Mono-Q & 0.50 & 3.7 & 0.56 & 200 \\
Superose 12 & 0.14 & 1.0 & 2.72 & 971 \\
\hline
\end{tabular}


Table 2. Peptides from purified porcine liver phosphohistidine phosphatase sequenced by MS. The amino acid sequences of peptides from the porcine enzyme are compared with the amino acid sequence (accession number AAF80759) corresponding to a cDNA from human adrenal glands (accession number AF164795). Amino acid sequencing by MS was performed as described under Experimental procedures.

\begin{tabular}{lll}
\hline $\begin{array}{l}\text { Peptide } \\
\text { number }\end{array}$ & Sequence & $\begin{array}{l}\text { Homologous } \\
\text { sequence } \\
\text { in AAF80759 }\end{array}$ \\
\hline 1 & LAAADLAQIPDVDIDSDGVFK & $1-21$ \\
2 & KWAEYHADIYDK & $48-59$ \\
3 & GLDCECLGGGR & $68-78$ \\
4 & SVTWADDGY & $117-125$ \\
\hline
\end{tabular}

\section{Cloning and expression of a human 14-kDa phosphohistidine phosphatase}

Based on the human sequence data a pair of primers was designed for PCR cloning using a cDNA-library derived from human embryonic kidney cells as template. The 378-bp cDNA-fragment obtained was confirmed by sequencing to be identical to the human cDNA reported (AF164795). This DNA-fragment was inserted into an expression vector and the expression in bacteria was induced by isopropyl thio- $\beta$-D-galactoside. The phosphohistidine phosphatase activity in the bacterial lysate was about 40 -fold higher than that observed with bacteria not treated with isopropyl thio- $\beta$-D-galactoside. After purification to apparent homogeneity, the recombinant protein displayed a phosphohistidine phosphatase activity towards phosphopeptide I. The specific activity was $9 \mu \mathrm{mol} \cdot \mathrm{min}^{-1} \cdot \mathrm{mg}^{-1}$ at $\mathrm{pH}$ 7.5. At $\mathrm{pH} 5.6$, the activity was only $2 \%$ of that at $\mathrm{pH}$ 7.5. No activity was detected at $\mathrm{pH} 9.0$. The $\mathrm{pH}$-dependence of the recombinant human enzyme was thus similar to that of the porcine liver enzyme.

The specificity of the recombinant enzyme towards phosphohistidine was supported by the finding that none of the eight O-phosphorylated peptides described under Experimental procedures were detectably dephosphorylated; i.e. the cleavage was $<0.01 \mathrm{nmol} \cdot \mathrm{min}^{-1}$ in experiments with an amount of phosphatase sufficient to cleave $\mathrm{N}$-phosphorylated phosphopeptide I in the standard assay at the rate of $0.30 \mathrm{nmol} \cdot \mathrm{min}^{-1}$.

The purified human recombinant phosphohistidine phosphatase showed only one band in SDS/PAGE, with an apparent molecular mass of about $14 \mathrm{kDa}$. Upon chromatography on a Superdex 75 PC 3.2/30 column, the active human enzyme migrated as $13.7-\mathrm{kDa}$ bovine pancreatic ribonuclease (data not shown). Thus, the recombinant protein was active as a monomer, as was the case also with the purified porcine enzyme. The nucleotide sequence of the cloned human cDNA and the corresponding amino acid sequence are shown in Fig. 1. The identity of the expressed protein was confirmed by amino acid sequencing of tryptic peptides (Fig. 1, underlined sequence segments). The analysis showed that the $\mathrm{N}$-terminal peptide lacked the $\mathrm{N}$-terminal formyl-Met expected from the nucleotide sequence. This finding was confirmed by MS-analysis of the intact, purified recombinant protein, which displayed a molecular mass of $13700 \mathrm{Da}$ (Fig. 2), compatible with the

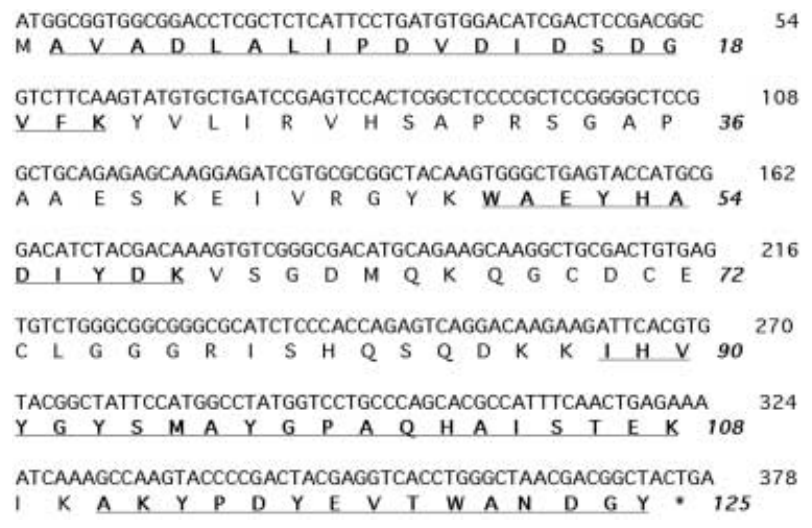

Fig. 1. Nucleotide sequence of cloned cDNA from human embryonic kidney cells, and the corresponding amino-acid sequence of the recombinant protein. The sequence data have been submitted to GenBank under the accession number AF393504. The underlined sequences indicate tryptic fragments derived from the purified recombinant protein and sequenced by MS, as described under Experimental procedures.

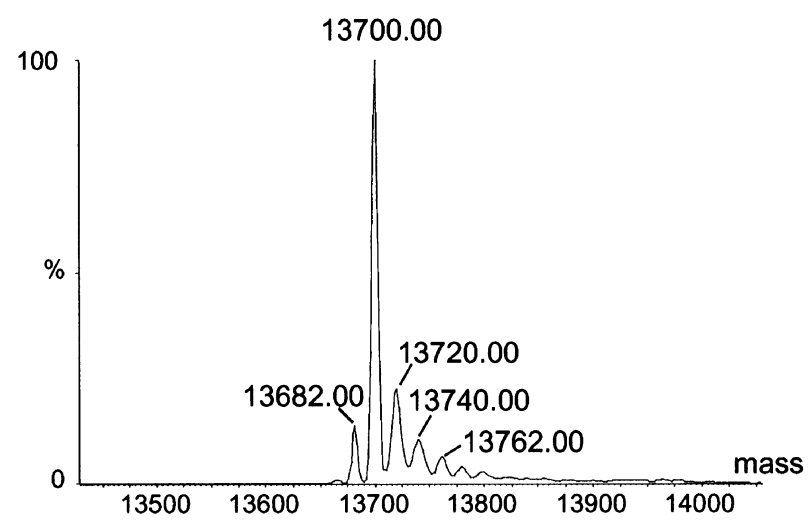

Fig. 2. MS of recombinant human phosphohistidine phosphatase. MS was performed as described under Experimental procedures. Deconvoluted and declustered $\left(\mathrm{M}+\mathrm{H}^{+}\right)$mass peaks were collected between 13400 and 14100 .

average molecular mass (13 $701 \mathrm{Da})$ calculated for the polypeptide containing amino acids $2-125$ of the predicted sequence. The MS-data, collected under standard conditions for obtaining the protein mass, did not indicate the existence of any cofactors tightly bound to the enzyme.

The recombinant phosphohistidine phosphatase had apparently been subjected to $\mathrm{N}$-terminal processing in the bacteria, since both the expected $\mathrm{N}$-formyl group of $\mathrm{N}$-terminal formyl-Met and the Met itself were absent. This usually occurs when alanine is the second amino acid [28]. Whether this alanine is the natural N-terminus of the phosphatase in human tissues remains to be determined.

\section{Messenger RNA expression}

When the full coding sequence for the human phosphohistidine phosphatase was used as the probe in a human multiple tissue Northern blot, we found that a $0.6-\mathrm{kb}$ 


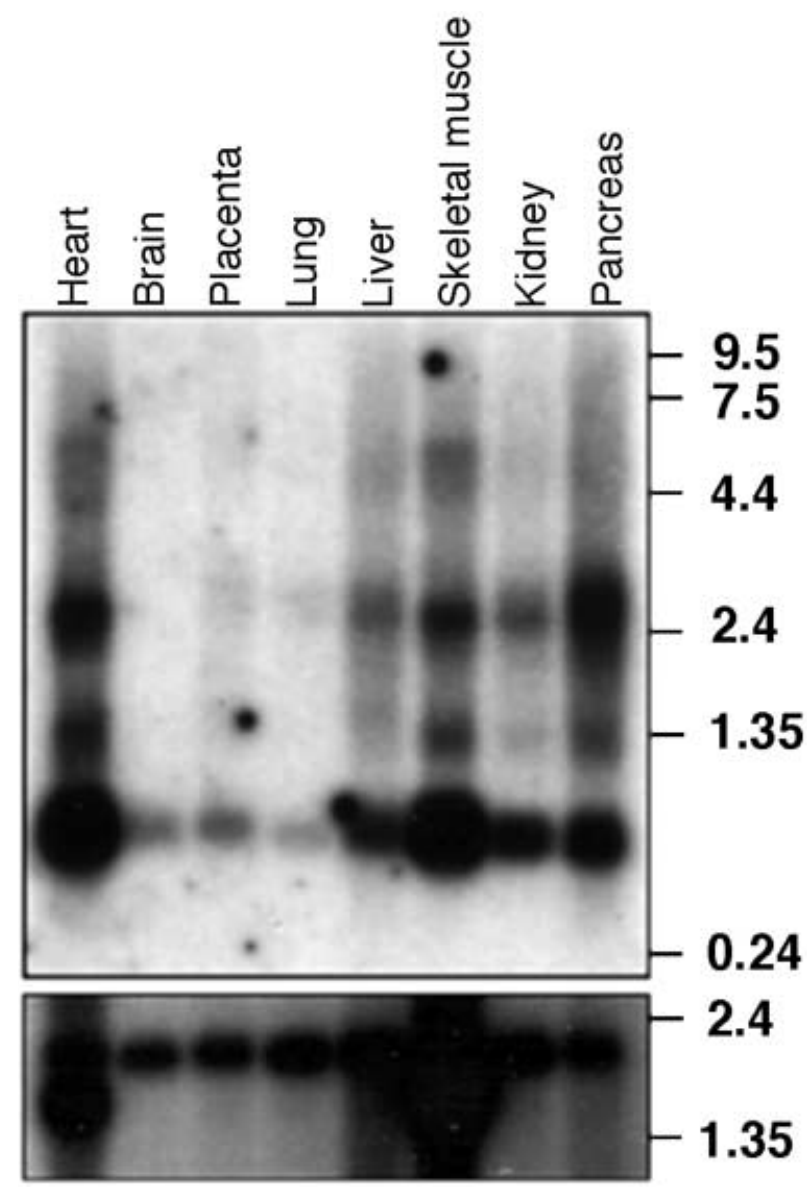

Fig. 3. Expression of histidine phosphatase mRNA in human tissues. A human multiple-tissue Northern blot was hybridized with human phosphohistidine phosphatase cDNA (upper panel) and $\beta$-actin cDNA (lower panel). The full-length cDNA probes were labelled with $\left[{ }^{32} \mathrm{P}\right] \mathrm{dCTP}$ in a reaction with Klenow enzyme. The hybridization was carried out in ExpressHyb Hybridization Solution (Clonetech) at $60{ }^{\circ} \mathrm{C}$ for $1 \mathrm{~h}$ and the blot was then washed with $0.1 \times \mathrm{NaCl} / \mathrm{Cit}$ containing $0.5 \%$ SDS at $60\left({ }^{\circ} \mathrm{C}\right)$. The membrane was exposed to an $\mathrm{X}$ ray film for 2 days. The mRNA-size $(\mathrm{kb})$ is indicated at the right margin.

mRNA, i.e. the size of AF164795, was expressed predominantly in the heart and skeletal muscle tissue, whereas the expression in liver was comparatively low (Fig. 3). Heart, skeletal muscle and pancreas in particular also contained larger sized mRNA that hybridized with the probe.

\section{Sequence comparisons}

Homologues were found in a few species when the amino acid sequence of human phosphohistidine phosphatase was used as the query for searching translated sequences of nonredundant nucleotide and EST databases at the NCBI site. No putative conserved domains were displayed. The alignment is shown in Fig. 4. When the nucleotide sequence of the putative mRNA of the human phosphatase (AF164795) was used as the query, the phosphatase gene was found to be located on chromosome 9 (9q34.3). Comparison with the continuous nucleotide sequence of this part of the chromosome (accession number AL355987) showed that the phosphatase gene contains three exons (Fig. 5). A sequence of 82 bp of the noncoding-3'-terminus overlaps with the noncoding 5 -terminus of another gene of unknown function in human. The mRNA (accession number XM_088463) corresponding to the latter gene showed homology to the mRNA of a rat apical endosomal glycoprotein (accession number L37380).

\section{DISCUSSION}

The present work describes the detection, isolation and partial amino acid sequencing of a porcine liver $14-\mathrm{kDa}$ phosphohistidine phosphatase, and the consequential identification, cloning and expression of a corresponding, human $14-\mathrm{kDa}$ phosphohistidine phosphatase. The fortunate choice of the phosphohistidine-containing peptide Suc-Ala-His(P)-Pro-Phe-pNA (phosphopeptide I) as the probing substrate was essential for this outcome.

Phosphatases 1, 2A and $2 \mathrm{C}$ represent most of the protein phosphohistidine phosphatase activity in liver cytosol when assayed with $5 \mu \mathrm{M}$ phosphohistidine-containing histone $\mathrm{H} 4$ [29]. This activity was about twofold higher than that observed in the present work using phosphopeptide I. Still, the dephosphorylation of the phosphopeptide by porcine liver cytosol was apparently not due to protein phosphatases 1,2A and 2C as judged from the lack of inhibition by okadaic acid and EDTA. Phosphopeptide I therefore seems to be a suitable substrate for estimates of the 14-kDa phosphohistidine phosphatase activity in crude extracts that also contain other phosphatases.

The identification of natural substrates of the 14-kDa phosphohistidine phosphatase will be a major task in the
Fig. 4. Alignment of human phosphohistidine phosphatase to homologous proteins. The amino acid sequence of human phosphohistidine phosphatase (Fig. 1) was used as the query in a search against translated sequences of nonredundant nucleotide and EST databases at the NCBI site (http:// www.ncbi.nlm.nih.gov/blast). For alignment to the human query sequence, homologous mouse, bovine and porcine sequences were selected.

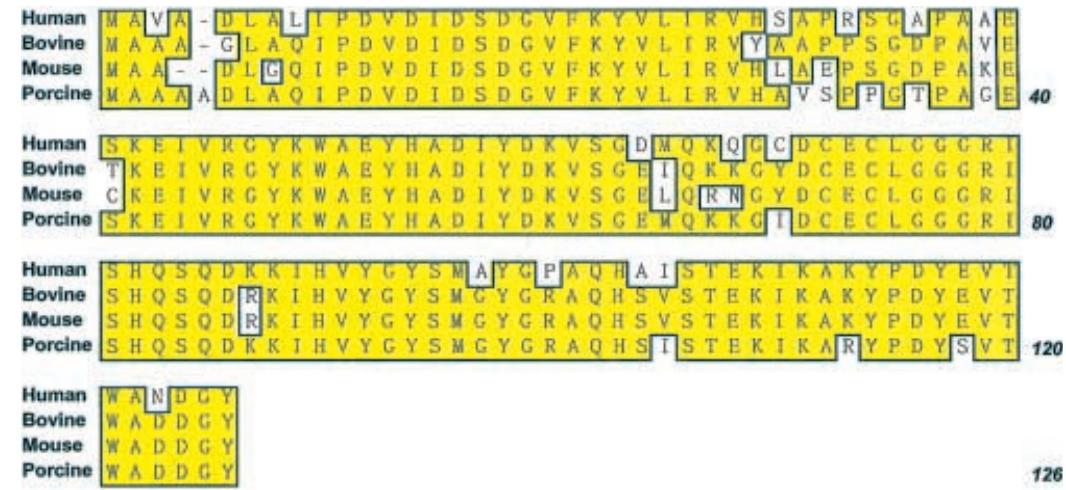




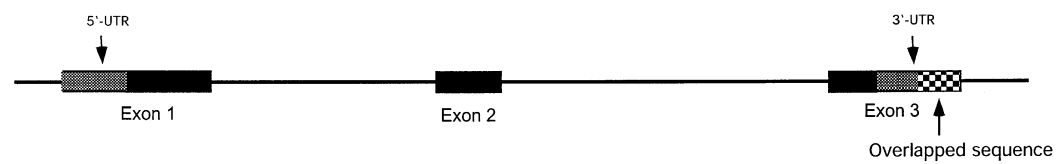

Fig. 5. Putative genomic organization of the human phosphohistidine phosphatase gene. A standard BLAST search, with AF164795 as the query, was performed against the nonredundant databases at the NCBI site. In that way, the gene of the human phosphohistidine phosphatase was found to be located on chromosome 9 (9q34.3) and to contain three exons. The coding sequences are shown as black boxes, and the noncoding sequences as grey boxes. Horizontal lines represent introns. Overlap between the noncoding-3'-end of the human phosphohistidine phosphatase gene and the noncoding $5^{\prime}$-end of a gene, corresponding to a mRNA (accession number XM_088463) with similarity to a rat apical endosomal protein mRNA (accession number L37380), is represented by a checked box.

future investigation of the physiological role of the enzyme. A few conditions may be worth considering in this context.

Firstly, one group of phosphohistidine-containing proteins to be considered as possible natural substrates of the phosphohistidine phosphatase is that of enzymes that are intermediary phosphorylated on a histidine of the active site. Hiraishi et al. reported on the dephosphorylation of nucleoside diphosphate kinase in their study of the 13-kDa bovine liver phosphoamidase [15], which also has some properties similar to the 14-kDa phosphatase. However, the rate of this dephosphorylation, as calculated from their data, appears to be slower by several orders of magnitude than the rates reported for the dephosphorylation elicited by physiological concentrations of native substrates, such as ADP, cf [30,31]. The direct contribution by the phosphoamidase activity to the in vivo turnover of the phosphohistidine of nucleoside diphosphate kinase may therefore be negligible. A similar reservation may be worth consideration also for other combinations of phosphatases and intermediary phosphorylated enzymes. Therefore, kinetic data on the dephosphorylation of autophosphorylated ATP-citrate lyase in the paper in press by Klumpp et al. [17] will be highly interesting in this context.

Secondly, no further clues to the physiological role of the phosphatase were obtained when a translated BLAST search was performed against nonredundant nucleotide and EST databases at the NCBI site, though homologues were found in a few species. Alignment of the human, mouse, bovine and porcine sequences (Fig. 4) showed that the protein is considerably conserved, indicating an important functional role of the phosphatase. It is noteworthy that none of these proteins have so far been assigned an enzymatic activity, except a human amino acid sequence (CAC16267) retrievable from the patent division of GenBank. This sequence was referred to as 'protein histidine phosphatase' from its homology with the rabbit-liver protein histidine phosphatase, studied by Klumpp et al. [17].

Thirdly, the gene of the phosphohistidine phosphatase was found to overlap with a gene showing homology to the mRNA of a rat apical endosomal glycoprotein which is targeted to early endosomes [32,33]. Whether the small amounts of larger sized mRNA seen in the Northern blot in addition to the $0.6 \mathrm{~kb}$ mRNA mirrors alternative splicing remains to be studied. A putative simultaneous expression of the $14-\mathrm{kDa}$ phosphohistidine phosphatase and an endosomal protein may be of interest in the light of the recently described histidine phosphorylation of annexin I from a membrane preparation of ovine tracheal epithelia [34]. Although the detailed subcellular location of the phosphorylated annexin I was not reported, and the effect of the 14-kDa phosphatase on phosphorylated annexin I is still unknown, it is worth noting that annexin I shows endosomal binding in live HeLa cells [35].

In conclusion, the native substrates of the $14-\mathrm{kDa}$ phosphohistidine phosphatase described in the present work remain to be identified, but the mere existence of this unique phosphatase should offer new possibilities to the area of eukaryotic histidine phosphorylation and dephosphorylation.

\section{A C K N O W LE D GEMENTS}

We thank Dr Helena Larsson for stimulating discussions during the initial phase of this project and Dr Åsa Haglund for valuable help with the layout of the manuscript. The work has been funded by the Swedish Medical Research Council (Project 13X-04485), Swedish Agricultural and Forestry Research Council (Project 729.1181/97), and by Polysackaridforskning AB, Uppsala.

\section{REFERENCES}

1. Boyer, P.D., DeLuca, M., Ebner, K.E., Hultquist, D.E. \& Peter, J.B. (1962) Identification of phosphohistidine in digests from a probable intermediate of oxidative phosphorylation. J. Biol. Chem. 237, 3306-3308.

2. Mitchell, R.A., Butler, L.G. \& Boyer, P.D. (1964) The association of readily-soluble bound phosphohistidine from mitochondria with succinate thiokinase. Biochem. Biophys. Res. Commun. 16, $545-550$.

3. Matthews, H.R. (1995) Protein kinases and phosphatases that act on histidine, lysine, or arginine residues in eukaryotic proteins: a possible regulator of the mitogen-activated protein kinase cascade. Pharmacol. Ther. 67, 323-350.

4. Wei, Y.F. \& Matthews, H.R. (1991) Identification of phosphohistidine in proteins and purification of protein-histidine kinases. Methods Enzymol. 200, 388-414.

5. Fothergill-Gilmore, L.A. \& Watson, H.C. (1989) The phosphoglycerate mutases. Adv. Enzymol. Relat. Areas Mol. Biol. 62, 227-313.

6. Elshourbagy, N.A., Near, J.C., Kmetz, P.J., Wells, T.N.C., Groot, P.H.E., Saxty, B.A., Hughes, S.A., Franklin, M. \& Gloger, I.S. (1992) Cloning and expression of a human ATP-citrate lyase cDNA. Eur. J. Biochem. 204, 491-499.

7. Schwander, W.R.E., Jiménez, B., Schwartz, A., Weijer, C.J., Behrens, M., Mazón, M.J. \& Fernández-Renart, M. (1993) Chemotactic stimulation of aggregation-stage Dictyostelium cells induces rapid changes in energy metabolism, as measured by succinic thiokinase phosphorylation. Biochim. Biophys. Acta 1176, 175-182.

8. Moréra, S., Chiadmi, M., LeBras, G., Lascu, I. \& Janin, J. (1995) Mechanism of phosphate transfer by nucleoside diphosphate kinase: X-ray structures of the phosphohistidine intermediate of 
the enzymes from Drosophila and Dictyostelium. Biochemistry 34, 11062-11070.

9. Gottlin, E.B., Rudolph, A.E., Zhao, Y., Matthews, H.R. \& Dixon, J.E. (1998) Catalytic mechanism of the phospholipase D superfamily proceeds via a covalent phosphohistidine intermediate. Proc. Natl Acad. Sci. USA 95, 9202-9207.

10. Okar, D.A., Live, D.H., Devany, M.H. \& Lange, A.J. (2000) Mechanism of the bisphosphatase reaction of 6-phosphofructo2-kinase/fructose-2,6-bisphosphatase probed by ${ }^{1} \mathrm{H}-15 \mathrm{~N}$ NMR spectroscopy. Biochemistry 39, 9754-9762.

11. Matthews, H.R. \& Chan, K. (2001) Protein histidine kinase. Methods Mol. Biol. 124, 171-182.

12. Huang, J., Wei, Y., Kim, Y., Osterberg, L. \& Matthews, H.R. (1991) Purification of a protein histidine kinase from the yeast Saccharomyces cerevisiae. The first member of this class of protein kinases. J. Biol. Chem. 266, 9023-9031.

13. Kim, Y., Huang, J., Cohen, P. \& Matthews, H.R. (1993) Protein phosphatases $1,2 \mathrm{~A}$, and $2 \mathrm{C}$ are protein histidine phosphatases. J. Biol. Chem. 268, 18513-18518.

14. Kim, Y., Pesis, K.H. \& Matthews, H.R. (1995) Removal of phosphate from phosphohistidine in proteins. Biochim. Biophys. Acta 1268, 221-228.

15. Hiraishi, H., Yokoi, F. \& Kumon, A. (1999) Bovine liver phosphoamidase as a protein histidine/lysine phosphatase. J. Biochem. 126, 368-374.

16. Klumpp, S. \& Krieglstein, J. (2002) Phosphorylation and dephosphorylation of histidine residues in proteins. Eur. J. Biochem. 269, 1067-1071.

17. Klumpp, S., Hermesmeier, J., Selke, D., Bechmann, G., Krieglstein, J., Van den Brulle, J., Weidner, G., Sharm, B., Güssow, D., Baumester, R. \& Kellner, R. (2002) Vertebrate protein histidine phosphatase: identification and functional studies. EMBO Reports, in press.

18. Reimer, U., El Mokdad, N., Schutkowski, M. \& Fischer, G. (1997) Biochemistry 36, 13802-13808.

19. Haglund, Å., Ronquist, G., Frithz, G. \& Ek, P. (2000) Alteration of the fibrinogen molecule and its phosphorylation state in myocardial infarction patients undergoing thrombolytic treatment. Thromb. Res. 98, 147-156.

20. Medzihradszky, K.F., Phillipps, N.J., Senderowicz, L., Wang, P. \& Turck, C.W. (1997) Synthesis and characterization of histidinephosphorylated peptides. Protein Sci. 6, 1405-1411.

21. Martin, J.B. \& Doty, D.M. (1949) Determination of inorganic phosphate. Modification of isobutyl alcohol procedure. Anal. Chem. 21, 965-967.

22. Stoscheck, C.M. (1990) Quantitation of protein. Methods Enzymol. 182, 50-68.
23. Laemmli, U.K. (1970) Cleavage of structural proteins during the assembly of the head of bacteriophage T4. Nature 227, 680685 .

24. Wilm, M., Shevchenko, A., Houthaeve, T., Breit, S., Schweigerer, L., Fotsis, T. \& Mann, M. (1996) Femtomole sequencing of proteins from polyacrylamide gels by nano-electrospray mass spectrometry. Nature 379, 466-469.

25. Sambrook, J., Fritsch, E.F. \& Manniatis, T. (1989) Molecular Cloning: a Laboratory Manual, 2nd edn. Cold Spring Harbor Laboratory, Cold Spring Harbor, NY.

26. Bradford, M.M. (1976) A rapid and sensitive method for the quantitation of microgram quantities of protein utilizing the principle of protein-dye binding. Anal. Biochem. 72, 248-254.

27. Hu, R.M., Han, Z.G., Song, H.D., Peng, Y.D., Huang, Q.H., Ren, S.X., Gu, Y.J., Huang, C.H., Li, Y.B., Jiang, C.L., Fu, G., Zhang, Q.H., Gu, B.W., Dai, M., Mao, Y.F., Gao, G.F., Rong, R.YeM., Zhou, J., Xu, S.H., Gu, J., Shi, J.X., Jin, W.R., Zhang, C.K., Wu, T.M., Huang, G.Y., Chen, Z., Chen, M.D. \& Chen, J.L. (2000) Gene expression profiling in the human hypothalamuspituitary-adrenal axis and full-length cDNA cloning. Proc. Natl Acad. Sci. USA 97, 9543-9548.

28. Meinnel, T., Mechulam, Y. \& Blanquet, S. (1993) Methionine as translation start signal: a review of the pathway in Escherichia coli. Biochimie 75, 1061-1075.

29. Matthews, H.R. \& MacKintosh, C. (1995) Protein histidine phosphatase activity in rat liver and spinach leaves. FEBS Lett. 364, 51-54.

30. Wålinder, O., Zetterqvist, Ö. \& Engström, L. (1969) Intermediary phosphorylation of bovine liver nucleoside diphosphate kinase. Studies with a rapid mixing technique. J. Biol. Chem. 244, 10601064.

31. Schaertl, S., Konrad, M. \& Greeves, M.A. (1998) Substrate specificity of human nucleoside-diphosphate kinase revealed by transient kinetic analysis. J. Biol. Chem. 273, 5662-5669.

32. Speelman, B.A., Allen, K., Grounds, T.L., Neutra, M.R., Kirschhausen, T. \& Wilson, J.M. (1995) Molecular characterization of an apical early endosomal glycoprotein from developing rat intestinal epithelial cells. J. Biol. Chem. 270, 1583-1588.

33. Wilson, J.M. \& Colton, T. (1997) Targeting of an intestinal apical endosomal protein to endosomes in nonpolarized cells. J. Cell Biol. 136, 319-330.

34. Muimo, R., Hornickova, Z., Riemen, C.E., Gerke, V., Matthews, H. \& Metha, A. (2000) Histidine phosphorylation of annexin I in airway epithelia. J. Biol. Chem. 275, 36632-36636.

35. Rescher, U., Zobiak, N. \& Gerke, V. (2000) Intact $\mathrm{Ca}^{2+}$-binding sites are required for targeting of annexin 1 to endosomal membranes in living HeLa cells. J. Cell Sci. 113, 3931-3938. 